\title{
Centro de Estudos Ameríndios da USP - CEstA
}

A formação do Centro de Estudos Ameríndios, ou CEstA, em 2011, instaura um diálogo interdisciplinar a respeito de questóes pertinentes ao conhecimento dos povos indígenas das Américas. Ao reunir pesquisadores de diferentes áreas, o Centro tem como objetivo produzir, aprofundar, sistematizar e divulgar conhecimentos sobre os ameríndios.

Sua equipe proponente reúne especialistas da Faculdade de Filosofia, Letras e Ciências Humanas (Departamentos de Antropologia e História), Museu de Arqueologia e Etnologia, Instituto de Estudos Brasileiros e Instituto de Matemática e Estatística (Departamento de Ciência da Computação) ${ }^{1}$. Esses pesquisadores já conduzem suas pesquisas no âmbito de paisagens essencialmente multidisciplinares, mas a criação do CEstA visa instaurar esse debate com a densidade necessária para gerar, em cada pesquisa e em conjunto, novos conhecimentos e novas indagaçóes.

Vale salientar que o CEstA tem como horizonte a incorporação de pesquisadores de outras áreas igualmente relevantes para o desenvolvimento de suas metas, como linguística, literatura, demografia, estatística, musicologia, geografia, ecologia, etc. Na Universidade de Sáo Paulo, os centros de produção de conhecimento sobre povos ameríndios estão dispersos em diferentes departamentos e núcleos de pesquisa, tais como o Departamento de Antropologia, o Núcleo de História Indígena e do Indigenismo (NHII), o Laboratório de Imagem e Som em Antropologia (LISA), o Núcleo de Antropologia Urbana (NAU), o Museu de Arqueologia e Etnologia (MAE), o Departamento de História, o Centro de Estudos Mesoamericanos e Andinos (CEMA), e o Instituto de Estudos Brasileiros (IEB), entre muitos outros. A criação do CEstA permitirá o estabelecimento de um espaço de discussão, conectando esses centros e pesquisadores dispersos.

Sendo o núcleo proposto um espaço de debate interdisciplinar com foco em questôes ameríndias, cumpre, inicialmente, justificar seu recorte. A possibilidade e o interesse de considerar as populaçóes nativas da América em conjunto decorrem, em primeiro lugar, de uma história muito particular. $\mathrm{O}$ continente americano foi o último a ser ocupado por nossa espécie, Homo sapiens, há cerca de 15.000 anos; as pequenas populaçóes pioneiras logo se expandiram por toda parte; há 11.000 anos, todo o continente já estava ocupado, do Ártico à Patagônia, dos desertos áridos à Amazônia. Ao longo de milênios, os povos americanos ficaram relativamente isolados do resto do planeta até o início da colonização europeia e, ao mesmo tempo, deslocando-se através do continente. Envolvendo-se em redes mais ou menos extensas de intercâmbio, desenvolviam algo que pode ser considerado, num nível muito profundo, como especificamente ameríndio. Justifica-se, assim, o interesse de reunir estudiosos dedicados a contextos ameríndios em vários tempos e regióes.

Entre as atividades propostas, incluem-se disciplinas a serem construídas e ministradas em conjunto por diferentes especialistas e o incentivo à participação dos alunos nas atividades de pesquisa e de difusão do Centro. Também está prevista a elaboração conjunta de novos projetos para financiar atividades de pesquisa colaborativa, com a participação dos alunos.

Ao longo do primeiro triênio de atividades, os debates dessa equipe multidisciplinar serão organizados em torno de três feixes de ques- 
tôes. O primeiro, "fontes amerindias", visa refletir sobre formas de expressão e registro de culturas ameríndias, e sobre o modo como são concebidas e incorporadas à reflexão nas diferentes linhas disciplinares. O segundo, denominado "estruturas ameríndias" abordará tanto as formas de organização sociopolítica em diferentes tempos e espaços como práticas de conhecimento e suas transformaçóes, regimes de relação com os ambientes, etc. $\mathrm{O}$ terceiro feixe de questóes tratará dos modos pelos quais os povos ameríndios experimentam as diversas situaçóes postas pelo mundo moderno - caracterizado pela economia de mercado capitalista, pelo crescimento de centros urbanos cosmopolitas, pelos corolários político-epistemológicos da revolução científica do século XVII, e pela expansão do modelo de política representativa e democrática.

Se o conhecimento aprofundado e renovado dos mundos ameríndios proposto é, em si, algo que não precisa ser justificado, acrescenta-se a esse plano puramente acadêmico a relevância dos estudos ameríndios para o debate de temáticas relativas ao mundo contemporâneo em suas dimensóes globais. Basta pensarmos no lugar de protagonistas que povos indígenas de todo o mundo, mais especialmente das Américas e mais particularmente da Amazônia, têm ocupado nos debates sobre biodiversidade, multiculturalismo, aquecimento global, patrimônio, periferização, conhecimentos tradicionais e outros. Por outro lado, experiências recentes, como a boliviana e a equatoriana, colocam em causa conceitos de nação, projetos de multiculturalismo e possibilidades de articulação entre tradições nativas e instituições estatais, todas questóes atualíssimas e fundamentais.

Em suma, a criação do novo Centro qualificará a Universidade de São Paulo como um importante interlocutor dos diversos departamentos, núcleos, centros e projetos de pesquisa dedicados à produção de conhecimento relativa a povos ameríndios.

\section{Notas}

1. A equipe do CEstA é formada pelos seguintes docentes: Dominique Tilkin Gallois, Eduardo Góes Neves, Beatriz Perrone-Moisés, Carlos Eduardo Ferreira, Eduardo Natalino dos Santos, Fabíola Andréa Silva, José Guilherme Cantor Magnani, Márcio Ferreira da Silva, Marta Rosa Amoroso, Renato Sztutman, Stelio Alessandro Marras e Sylvia Caiuby Novaes. 